\title{
タイマー機能をもつタンパク質
}

\section{休眠にかかわるエステラーゼ $\mathrm{A}_{4}$ に測時機能?}

生物時計の情報は, 生体の化学的 - 生理的過程, 行動 のタイミングなど多様の制御に用いられている. 体内時 計としては，約 24 時間周期でまわる概日時計のような リズム時計と, 時間の長さをはかるインターバルタイマ 一とが考えられ，リズムについては，その分子機構がシ ヨウジョウバエの変異体を使って解明されつつある(1). 一方，インターバルタイマーについては，そうした機能 をもつと推察されるタンパク質が, カイコから単離され ている(1).

ショウジョウバェでは羽化する個体の最も多くなるピ ークがほぼ 24 時間掞きにみられる.このリズムに関す る 1 遺伝子変異体として, 約 19 時間の短周期型 $\left(p e r^{s}\right)$, 29 時間の長周期型 (per $\left.{ }^{1}\right)$ および無周期型 $\left(p e r^{0}\right)$ が得 られている. 羽化は各個体にとって一生に 1 回しか起こ らないことであるが, 活動のリズムと深い関係にある. 正常には, 昼は活発に動き, 夜は静かな約 24 時間のリ ズムである. ところが, 上記変異体の場合には, その活 動リズムが羽化のリズムとまったく同じ 19 時間, 29 時 間および無周期なのである. その他のリズムにも同じ傾 向がある. 雄は, 交尾行動の前に断続的に趐を振動させ る.この求愛ソングのリズムが, 野生系の 55 秒に対し て, per ${ }^{\mathrm{s}}$ では短い 40 秒, per ${ }^{1}$ では長い 80 秒であり, per ${ }^{0}$ ではリズムが消失している. 心拍リズム, 唾腺への 色素とり込みリズム, チロシンデカルボキシラーゼなど の酵素活性, $\operatorname{poly}(\mathrm{A})+$ RNA 量の日周変動などにも同 じ傾向がみられる.

per は時計の本体を形成する遺伝子であり, リズムに かかわるタンパク質をコードしていると考えられる．変 異は点突然変異である. DNA 上の 1 個の塩基のちがい がアミノ酸のちがいとなり，わずか 1 個のアミノ酸のち がいで，時計の刻も時間が伸縮する，種々のリズムとの 関係はさらに興味深い. per タンパク質のアミノ酸配列 の中に，スレオニンーグリシンを想定させる DNA 上の 反復配列がある。この反復配列を欠いた DNA を遺伝子 工学的に作り, per $^{0}$ 個体に導入すると, 活動リズムは正
常の 24 時間に回復するが，求愛ソングは正常より短い 40〜46 秒のリズムになる. 異なる行動のリズムが， 1 個 のタンパク質の 異なる部位と関係していることがわか る.

一定周期で繰り返されるリズムに対して，発生を進め る時計などといわれ，分化・発育過程で不可逆的に進行 する諸現象とかかわる時計がある. 遺伝子の差次的発現 に関係しているはずである.このインターバルタイマー に関する分子レベルの研究は，現在ほとんどない，

筆者らは，昆虫の休眠について考えてきた(1). 休眠に は一定の持続期間があり，インターバルタイマー型生物 測時現象である. タイマー機能をもつ可能性の推察され るタンパク質は，この休眠に関する研究のプロセスで見 いだされた。

カイコ卵の休眠は，休眠ホルモンの誘導による．その ホルモン作用の 1 つとして, エステラーゼA（Ease A) と呼ばれる酵素の活性抑制があげられる．この酵素と臕 発育とは密接な関係にあり, 卵を塩酸に浸漬（浸酸：荲 糸業での重要な操作）して非休眠化すると，Ease A 活

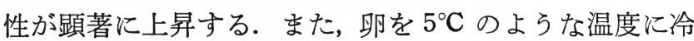
蔵しても, Ease A 活性は上昇する(2).

カイコ休眠卵を冷蔵すると，孵化能力がついてくる (休眠離脱). しかし，冷蔵による Ease A 活性の上昇は 休眠が破れた結果ではない. そらであれば, Ease A 活 性の上昇しはじめた卵を発育適温である $25^{\circ} \mathrm{C} に$ 移せ ば，胚発育が活発となるはずである，ところが実際に は，25ㄷ に保護しても休眠をつづける．休眠が破れるた めには，Ease A 活性が上昇しきらねばならないのであ る. Ease A は複数の成分からなり, 支 108 号といら品 種では, このうち Ease $\mathrm{A}_{4}$ が上昇する. 卵の冷蔵によ る Ease $\mathrm{A}_{4}$ 活性の上昇には, 酵素タンパク質の de novo 合成は伴っておらず，プロテアーゼによるプロセ シングやリン酸化など, 酵素活性上昇機構として知られ ている多くの現象については, ポジティブな結果が得ら れていない、試みに行なわれた実験は, 酵素を試験管で 
$5^{\circ} \mathrm{C}$ に冷蔵してみることであった. その結果, Ease $\mathrm{A}_{4}$ 活性は，10 日を過ぎると上昇しはじめ，冷蔵約 2 週間で 極大に達した. その後, この活性も急速に低下し, in vitro 冷蔵時に発現する活性上昇・極大活性期が, 卵を 冷蔵した場合と汪とんぞ同じという結果であった(3).

Ease $\mathrm{A}_{4}$ は, 卵のアセトン喏研, 熱処理, 硫安カッ ト,ゲル濾過和よび高速クロマトフォーカシングによっ て精製されている. 結晶として得られて掞り, 分子量約 25,000 ダルトンのモノマーである. in vitro 活性上昇 機構については，まだ十分な研究がなされていないが, 次のような点が明らかにされている.

精製度の高い酵素標品, 正確な活性測定といら一般的 な点に加えて, 次のことが要求されている. (1)酵素の精 製には，発育が $2 \sim 3$ 時間以内の範囲でそろった卵を使 5. (2) Sephadex G-25 ゲル 濾過排除分画中の 分子量 10,000 ダルトン以下の成分を, 酵素分画に混入させな い. (1)は酵素活性のピークのするどさに影響する. (2)は 酵素活性発現までの時間に影響し, 混在すると酵素活性 は発現しない.

活性な Ease $\mathrm{A}_{4}$ と不活性な Ease $\mathrm{A}_{4}$ とを混合して 舟，不活性化あるいは活性化されず，不活性な酵素はや はり約 2 週間で活性を現わす. Ease $\mathrm{A}_{4}$ 標品中にプロテ アーゼ活性は認められず, 種々のプロテアーゼ阻害剤共 存下でも活性は発現する. native および SDS-PAGE の易動度も活性発現前後で差異は認められない, 一旦活
性化された Ease $\mathrm{A}_{4}$ を冷蔵しつつけけても，低温だけで 再び活性化されることはない。ところが，長期冷蔵に よって完全失活した Ease $\mathrm{A}_{4}$ を $6 \mathrm{~m}$ 塩酸グアニジン ( $\mathrm{GHCl})$ で処理し，処理酵素を再泠蔵すると約 2 週間で 活性が発現する. 活性発現前に $\mathrm{GHCl}$ 処理しても同様で ある. すなわち, 冷蔵 8 日後の Ease $\mathrm{A}_{4}$ を $\mathrm{GHCl}$ 処理 して冷蔵をつづける, 冷蔵約 3 週間後, すなわち処理 約 2 週間後に活性が現われる.これらの結果は, Ease $\mathrm{A}_{4}$ の等電点（pH 3.85）扣よび卵内 $\mathrm{pH}(\mathrm{pH} 6.4)$ など酸 珄側でみられ、アルカリ側では活性発現までの時間が 8〜9 日と短くなる.

カイコ卵の休眠離脱機構は, 遺伝子発現調節機構に関 する実験のモデル系でもある. 一定の時間プログラムの 後に遺伝子の情報が一斉にオープンになり，活発な肧発 育が再開する. Ease $\mathrm{A}_{4}$ 活性は, in vitro で一定時間後 に一過性の発現をする．時間消費の現われではなく，時 間計測ではないだろらか. タイマー型測時機構に組み込 まれたシグナルタンパク質としての可能性が推察され得 る. タンパク質の構造の中に測時機能があるという仮説 のもとに，検討が進められている.

1）甲斐英則：“生物機能と時間一酵素が時間をはかる?’, “昆虫 学セミナー II", 中筋房夫編, 冬樹社, 1988, p. 249.

2) H. Kai \& K. Nishi : J. Insect Physiol., 22, 1315 (1976).

3) H. Kai, T. Kawai \& Y. Kawai : Insect Biochem., 17, 367 (1987).

(甲斐英則, 鳥取大学農学部)

\section{塩生植物はなぜ塩に強いのか? 耐塩性作物育種の可能性を探る}

我国で塩類障害と言えば，最近はハウス土壤への過剰 施肥によるものをまず思い浮かべるが，世界的規模でみ れば，乾燥，半乾燥気候下で農業を行ならときにまず遭 遇する, 土壤と灌溉水への塩類, 特にナトリウム塩など の集積に起因するものである，我国においても海沿いの 水田や干拓地において, 高潮や残存塩類による塩類障害 が認められるが，降水量が多く塩類は直ちに溶脱される ため，いずれも一時的な障害にとどまり，土壌学に言う 塩類土壤は我国には存在しない.

作物の塩類障害の程度は, その作物が栽培される地方
の土裹 (保水力, 塩分含有率), 気象条件 (気温, 降水 量, 降水時期), 灌溉水の塩分濃度, 品種, 栽培管理など にかなり左右される. したがって, 我国で作物の塩類過 唾障害について実験を行なおうとしても実験条件の設定 が難しく，ともすれば実験のための実験に終始する危険 をはらんでいる，そこで筆者らは，まず我国に自生し耐 塩性を持っている高等植物の耐塩機構を明らかにしょう と考えた.

塩類の集積している土堙でも生育することができる高 等植物を植物生態学の用語で塩生植物と呼び，一般に海 
水塩分濃度の $1 / 5$ に相当する $100 \mathrm{~mm} \mathrm{NaCl}$ 存在下で 開花, 結実しらるものとされている.ちなみにコシヒカリ を $100 \mathrm{~mm} \mathrm{NaCl}$ で栽培すると, 処理後 1 力月以内に枯 死してしまう.我国に自生する塩生植物にはアカザ科, キク科, イネ科, ナデシコ科の草本や南西諸島沿岸でみ られるマングローブと総称される木本のものがあるが, 作物として利用されているものはほとんどない.アカザ 科のアッヶシソウやハママッナは, かつて瀬戸内海に多 くあった塩田の雑草として知られていた. また, 河口に 繁るヨシも塩生植物と言える(1). 筆者らは, 岡山県牛空, 兵庫県赤穂の塩田跡地で採取したホソバノハマアカザ (Atriplex gmelini ; アカザ科) とヨシ (Phragmites communis；イネ科）を用いて実験を開始した.

高濃度の塩類がなぜ植物に生育障害をひき起こすかと いら命題についていろいろ検討されてきたが，現在では 主に, (1)高濃度塩類溶液の浸透圧が物理的に吸水を阻害 する，(2)根から塩類が体内に侵入して細胞の代謝反応を 阻害する，ことが原因と考えられている. (1) “青菜に 塩”で漬物を漬けるときの食塩による脱水を, (2)は魚や 肉の塩蔵を考学れば容易に理解できる. したがって, 塩 生植物ではこれらを回避する機構を持っていることが予 想される. 海水の $1 / 2$ に相当する $250 \mathrm{~mm} \mathrm{NaCl}$ を添加 した水耕培養液で栽培したホソバノハマアカザ（ホソバ と略す）とヨシの葉身から搾汁液を絞り, その浸透圧を 測定すると，ホソバ，ヨシとも 800 から $1,000 \mathrm{mOsmol}$ であった．この培養液の浸透圧は $460 \mathrm{mOsmol}$ であるか ら, 水は培養液から根を通り葉のほらに移動するが，作 物のそれは普通 200 から $300 \mathrm{mOsmol}$ であるので, 逆 に水を吸い出されて漬物になってしまう。つまり,この 高い葉身浸透圧が吸水力を生み出して拉り，ホソバでは その $90 \%$ が Na 塩でまかなわれ(2)， ヨシでは $60 \%$ が K塩, 30\% がシュークロース, $10 \%$ が Na 塩であっ

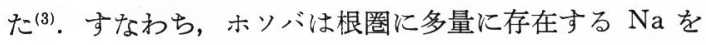
とり込み, 体内浸透圧をつくり出している. 栽培条件に よっては，ホソバの葉身には 500 から 1,000 m M $0 \mathrm{Na}$ が蓄積される. ヨシでは Naの吸収を抑え，K濃度を高 く保ち,さらに光合成産物であるシュークロースを蓄え て体内浸透圧を生み出していた.

葉身は植物にとって光合成を行なら大切な器官であ
る. 蓄積された塩類は光合成などの代謝に影響を与えな いのだろらか. 1970 年代に行なわれた一連の研究で, 塩 生植物由来の酵素の活性も塩類によって通常の植物のも のと同じように阻害されることが示された，では，吸収 された塩類はどこに存在しているのか. 組織化学的研究 から, 塩類は液胞に隔離されていることが示唆され, 実 際に, 単離された液胞に $\mathrm{Na}$ 塩が高濃度で蓄積している ことが示された (4). 液胞は高等植物に特有の器官で, 成 熟葉の場合, 細胞体積の $90 \%$ 以上を占める. 細胞質 は, 塩類が局在する液胞に水を奪われないために等張で なければならない、そのために，ホソバでは細胞質にべ タインを蓄積する. 葉身搾汁液当りのベタイン濃度は 30 から $80 \mathrm{~mm}$ 程度であるが, 液胞にはほとんど存在せ ず(4)，また細胞質の体積は細胞全体の $10 \%$ 以下なので, 細胞質での濃度は 600 から 1,600 mu となり, 液胞に 局在する塩類とほぼ同じ浸透圧を持つことができる. 2 м までのベタインはほとんど酵素反応を阻害しない。 ヨシの場合は恐らくシュークロースであろら，他の種で はソルビトールやプロリンが機能している可能性が報告 されている. しかし，これら有機溶質の蓄積も液胞に塩 類が隔離されてはじめて意味を持つのであって，プロリ ンやベタインを蓄積するからといって耐塩性があると考 えるのは早計である.

ここまで述べてきたように，ホソバの場合，耐塩性を 賦与している機構は, (1)根からの Naのとり込み, (2)こ の $\mathrm{Na}$ の液胞への閉じ込め, (3)細胞質へのベタインの蓄 積である. ホソバは培地 $\mathrm{NaCl}$ 濃度が $700 \mathrm{~mm}$ でも体 内 $\mathrm{Na}$ 濃度は $1 \mathrm{~m}$ 近くに保たれ, 生育速度は低いもの の健全であった. しかし， $\mathrm{KCl}$ では $200 \mathrm{~mm}$ 以上では枯 死してしまい(2), このときの体内K濃度は $2 \mathrm{M}$ を越えて いた. Na をとり达むといっても無秩序に吸収するので はなく，体内外の浸透圧差は保て，かつ過剰とはならな いようかなり精緻な制御が行なわれているようである. 塩生植物の中には塩囊や塩腺と呼ばれる塩類排出を行な ら器官を持つものもあるが, 植物体内外の浸透圧差維持 といら立場から考えると, これらの器官の耐塩性への寄 与はそれ法大゙大くはない. $\mathrm{Na}$ の液胞への閉じ込め機 構を検討するために, ホソパの液胞膜（トノプラスト） を単離し， Na との相互作用を検討したところ，単離し 
たトノプラスト小胞の, ATP に依存して形成された内 外のプロトン勾配 (内側酸性) は, Naイオンによって 崩壊し，同時に小胞内 $\mathrm{Na}$ 濃度が上昇した. この系の $\mathrm{Na}$ に対する $K_{\mathrm{m}}$ 值は $14 \mathrm{~mm}$ であった. また,このプ ロトン勾配はKイオンによってはまったく影響されなか った ${ }^{(5)}$. この結果は，ホソバの液胞膜にナトリウム/プロ トンのアンチポート機構が存在することを示している. 細胞質の $\mathrm{Na}$ 濃度は, 細胞質の種々の酵素活性の $\mathrm{Na}$ に対する感受性を考慮すると $50 \mathrm{~mm}$ 程度と考えられ， 一方, 液胞の $\mathrm{Na}$ 濃度は $600 \mathrm{~mm}$ 以上なので, $\mathrm{Na}$ は液 胞と細胞質の間でリーク/ポンプアップを繰り返してい ると考学られる. 両者の速度論的解析から細胞質の $\mathrm{Na}$ 濃度を推定できないか検討中である，ベタイン生合成経 路はホウレンソウやオオムギで検討されていて，セリ ンーエタノールアミンーコリンーベタインという経路が 提案されているが，ホソバでもほぼ同様のようである.

ヨシの場合は葉身に $\mathrm{Na}$ を貯め込まず，浸透圧は $\mathrm{K}$ 之 シュークロースで稼いでいる.ただし,培養液に Na が共 存しない場合でも $\mathrm{K}$ 濃度は高く, $\mathrm{Na}$ にっってKの吸収 が促進されるわけではない、つまり、ヨシでは(1) Na吸 収を低く抑える能力之, (2)強いK吸収力が耐塩性を賦与 していると考えられた. そこで，放射性の Naを用いて $\mathrm{Na}$ の動きを追跡すると, イネの場合は地上部への $\mathrm{Na}$ の集積は直線的に上昇していく単一相を示すのに対し, ヨシ地上部では吸収開始後 15 分くらいに集積速度が減 少する 2 つの相から成っていた. これは, 一旦地上部に 送られた Na が再度根に送り返されていることを示唆し
て敃り，さらにパルスチェイスを行なうと，放射性 $\mathrm{Na}$ が培養液中に検出された。この地上部からの $\mathrm{Na}$ の再転 流はイネでは見られず，また代謝阻害剤で阻害されるこ とから能動的な $\mathrm{Na}$ の排出であると考觉られた. 現在, その正体について検討中である.

塩生植物に耐塩性を与えている機構の生化学的背景の 解明はやっと緒についたばかりであるが，それは少なく ともそれほど単純ではないことだけはわかってきた。作 物の突然変異種の中から耐塩性の変異種を選抜しょうと する時，たとえば受精卵処理のような変異の幅の広い万 法を用いるとともに, 耐塩性の機構を考慮に入れた選抜 方法を用いなくてはいけない. $\mathrm{NaCl}$ を貯めるのか, 貯め ないのか, 貯めなければ何で浸透圧を維持しているのか. らなみにイネで耐塩性が強いと報告されている品種はヨ シ型の,トマトではホソバ型の耐塩性機構であった. し かし，実験室レベルで耐塩性品種が選抜されたとして も, 冒頭にも述べたように現地ではさらに耐乾性や耐暑 性, その品種の栽培のし易さ, 市場性も問題になってく るだろうから, 耐塩性品種育成のためには, 今後も地道 な努力を積み重ねていくしかないのが現状と言えよう.

1）高田英夫：“塩と生物”, 創元社, 1974.

2) T. Matoh, J. Watanabe \& E. Takahashi : Soil Sci. Plant Nutr., 32, 451 (1986).

3) T. Matoh, N. Matsushita \& E. Takahashi : Physiol. Plant., 72, 8 (1988).

4) T. Matoh, J. Watanabe \& E. Takahashi : Plant Physiol., 84, 173 (1987).

5) T.Matoh, T. Ishikawa \& E. Takahashi : Plant Physiol., 89, 180 (1989).

(間藤 徹, 京都大学農学部農芸化学科)

\section{tRNAのアイデンティティー}

\section{アミノアシル tRNA合成酵素はどのようにtRNAを識別するか?}

タンパク質生合成では, アミノ酸を結合したトランス ファーRNA（tRNA）がメッセンジャーRNA のコド ンを認識することにより，核酸の塩基配列として記され ている遺伝情報が, タンパク質のアミノ酸配列へと翻訳 される.ここで, どのコドンをどのアミノ酸に翻訳する かというルールが “遺伝暗号表”である。 また，るる tRNA がどのアミノ酸に特異的か(どのアミ)酸を運ぶ か) が, その tRNA の“アイデンティティー”となる.
すなわら，遺伝暗号とは，あるコドンを認識する tRNA がどのようなアイデンティティーをもつかによって定 められるものである.

それでは, tRNA の“アィデンティティー”は, どの ようにして決まるのであろらか. 20 種類のアミノ酸の それぞれに対して， 1 種類ずつのアミノアシル tRNA 合成酵素（ARS）が存在する，ARS はすず，担当する アミノ酸を活性化し, 続いて, そのアミ, 酸と対応すべ 
き tRNA（通常は複数）を選び出してアミノアシル化す る.もし，ARS が，活性化したアミノ酸を誤った tRNA に結合してしまうと, その tRNA の認識するコドンが 誤ったアミノ酸へと翻訳されることになってしまう． tRNA によるコドン認識, 遺伝子の転写, 複製などにお ける遗伝情報の認識・伝達が，すべて核酸-核酸相互作 用（塩基対形成）によっているのに対し，塩基配列から アミノ酸配列への“翻訳”は, ARS による厳密な分子 識別に全面的に依存しているのである.

ARS による tRNA 識別のメカニズムの研究は, 最 近, RNA 操作技術などの発展によって急速に進展し， 特に 1988 年になって, 重要な報告が相次いでなされ た. ARS が自分の担当する tRNA を他の tRNA から 識別するために認識する tRNA の構造上の特徴を, そ の tRNA の“アイデンティティー決定因子”と呼ぶよ らになり, いくつかの tRNA について, アイデンティ ティー決定因子が, 数ヌクレオチド残基といら狭い範囲 にあることがわかった.このような研究の過程で, 決定 因子を人為的に操作・变換し, tRNA のアイデンティテ ィーを, あるアミノ酸から他のアミノ酸へと改変するこ とも可能になった. このよらな研究の現状を紹介する.

まず，イソロインンに特異的な tRNA のアンチコド ン 1 字目の転写後修飾によるアミノ酸特異性の転換につ いて述べる. 遺伝暗号表で, コドン AUN のボックス は，イソロインンのコドン 3 個とメチオニンのコドン 1 個よりなる. 大腸菌については，2種のイソロイシン tRNA が知られており, $\mathrm{tRNA}_{1}{ }^{\mathrm{Ile}}$ (アンチコドン 1 字目 はG）がコドン AUU と AUC を認識するのに対し, $\mathrm{tRNA}_{2}{ }^{\mathrm{Ile}}$ はコドン AUA のみを認識する. 筆者らは, 最近, この $\mathrm{tRNA}_{2}{ }^{\mathrm{Il}} \mathrm{e}$ のアンチコドン 1 字目の未同定の 残基が，側鎖にアミノ酸のリシンを含むまったくの新規 の修飾ヌクレオシドであることを明らかにし, リシンと シチジンの誘導体と考光, リシジン (lysidine, 略号 L) と命名した(1).

実際に, この $\mathrm{tRNA}_{2}{ }^{\mathrm{Ile}}$ の遺伝子 (ileX) を単離したと ころ, $\mathrm{tRNA}_{2}$ Ile のアンチュドン 1 字目はCによってコ ードされていることが明らかになった。このように, $\mathrm{tRNA}_{2}{ }^{\mathrm{Ile}}$ は, アンチコドン 1 字目がCから L 修飾され ることにより, コドン 3 字目として $\mathrm{G} の$ 代わりに $\mathrm{A}$ を認
識するように転換されるのである(2).クリックの “wobble 塩基対”は, アンチュドン 1 字目の塩基が, ワトン ン・クリック型塩基対により認識する相手に加えて他 の塩基も認識するといらものである. これに対して, $\mathrm{tRNA}_{2}{ }^{\mathrm{Il}}$ に拈计るCから $\mathrm{L}$ への修飾は, 塩基対形成の 特異性を完全に転換するものである。これにより, ileX 遺伝子産物 tRNA では, メチオニンのコドンAUGを 認識するアンチコドン CAU が，1字目のCの転写後修 飾により LAUに変換されてはじめてイソロイシンのコ ドン AUA を認識するようになるのである.これは, tRNA のコドン特異性が転写後修飾により完全に切り換 えられるという最初の例である(2).

このように, ile $X$ 遺伝子から転写された直後の tRNA は, メチオニンのコドン AUG を認識することになる. この転写後修飾は, tRNA のコドン特異性のみを切り換 えて, アミノ酸特異性（アイデンティティー）には影響 を与えないことが予想された。すすなわち，アンチコドン 1 字目にGをもつ $\mathrm{tRNA}_{1}{ }^{\mathrm{Ile}}(\mathrm{GAU})$ と Lをもつ $\mathrm{tRNA}_{2}{ }^{\mathrm{Ile}}$ (LAU) とは, イソロイシンに特異的な ARS (イソロイ シル tRNA 合成酵素) により同程度によく認識され, イ ソロイシンを受容する．GとLとでは化学構造がまった く異なるので, この酵素はアンチコドン以外の部位を認 識しているように思われた。そうであるとすると, るし $\mathrm{C} \rightarrow \mathrm{L}$ といら修飾を受けない $\mathrm{tRNA}\left[\mathrm{tRNA}_{2}{ }^{\mathrm{Ile}}(\mathrm{CAU})\right]$ が存在すると，イソロイシル tRNA 合成酵素の基質 となってイソロイシンを受容し，メチオニンのコドン AUG をイソロイシンに翻訳してしまらことになり，細 胞にとって致命的であろう.

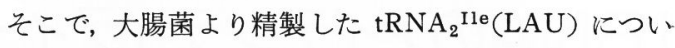
て，リボヌクレアーゼ， RNAリガーゼなどの処理によ り, アンチコドン 1 字目の L を未修飾のCへと置換し, この改变 $\mathrm{tRNA}_{2}{ }^{\mathrm{Il}}(\mathrm{CAU})$ のアミノアシル化反応を調べ た(2)ところ, 予想に反して、イソロイシン受容能が著し く低下していることがわかった。すなわち、アンチュド ン 1 字目の修飾ヌクレオシドLは, $\mathrm{tRNA}_{2}{ }^{\mathrm{Il}}$ のアイデン ティティー決定因子である. したがって，アンチコドン 1 字目が Lへ修飾されていない $\mathrm{tRNA}_{2}{ }^{\mathrm{Ile}}(\mathrm{CAU})$ が仮に 存在しても, イソロイシンを受容しないので,メチオニ ンのコドンAUG が誤ってイソロインンに翻訳されない 
ように制御されたのである(2).

さらに驚くべきことに, 改変 $\mathrm{tRNA}_{2}{ }^{\mathrm{Ile}}(\mathrm{CAU})$ は, × チオニル tRNA 合成酵素の基質となり, メチオニンを 効率よく受容することがわかった(2).すなわち、新たに 作られたアンチコドン CAU は, メチオニン tRNA と してのアイデンティティー決定因子であったのである. このため改変 $\mathrm{tRNA}_{2}{ }^{\mathrm{Ile}}(\mathrm{CAU})$ は, メチオニンのコドン AUG を認識するのみならず, メチオニンを受容できる ので,まさに“メチオニン特異的 tRNA”として機能し らる.以上のよらに, ile $X$ 遺伝子物質の tRNA におい ては, アンチュドン 1 字目のCからLへの，たった 1 個 所の転写後修飾が， tRNAのアイデンティティーをス イッチし，メチオニンとコドン AUG に特異的な tRNA から、イソロイシンとコドン AUA に特異的な tRNA へ転換されていることが明らかになった(2).

筆者らは，このような天然に拈ける tRNA アイデン ティティーの変換を，逆方向にたどったことになる．こ れと同じころ，自然現象とは無関係であるが，tRNAの アイデンティティーを人為的に変換したという報告が相 次いでなされたのである.それらは，tRNA のアイデン ティティー決定因子をつきとめるため，人為的に変異を 導入し，アイデンティティーの消失する個所を検索して ゆく研究による, 予想外の成果であった. Hou と Schimmel は, 大腸菌のアラニンに特異的な tRNA に対し て site-directed mutagenesis を系統的に行ない, 36 種 の変異体 tRNA を作製した(3). それらの变異体のらち で, 3 番目の $\mathrm{G}$ と 70 番目の $\mathrm{U}$ との間での wobble 塩基 対について, 一方または両方を変えた変異体 tRNA は, アラニル tRNA 合成酵素によって認識されなくなった. さらに, システインに特異的な tRNA に G(3): U （70）塩基対を導入すると, システインを受容せず, 代わ
りにアラニンを受容するようになったのである(3). ま た,フェニルアラニンに特異的な tRNA は, G( 3$)$ ： $\mathrm{U}(70)$ 塩基対の導入により，アラニンを多少は受容する ようになった(3). ほぼ同じころ, McClain と Foss も, 同様の研究成果を発表した(4). このように, $G(3)$ : U (70) 塩基対は, tRNA がアラニル tRNA 合成酵素によ って認識されるための(アラニン tRNA としてのアイ デンティティーの）主要な決定因子であることが明らか になった.

これに引き続き,アメリカの数グループが, tRNAの アイデンティティー決定因子の検索や, 人為的なアイデ ンティティー変換について, 相次いで報告しており, 大 きな話題となっている. そのような状況については, Schulman と Abelson ${ }^{(5)}$ および Yarus ${ }^{(6)}$ によって解説さ れている. ヨーロッパ勢も負けてはならぬとがんばって いるよらである. わが国でも, 京都大学の志村令郎博 土，小関治男博士らによる 先駆的な業績があり，現在 も, 西川一八博士 (名古屋大学理学部) などいくつかの グループが, tRNA のアイデンティティーの研究に取 り組んでいる.この勢いでは数年のうちに，すべての tRNA のアイデンティティー決定因子が解明され, 遺伝 暗号の本質に関する理解が大きく進展することも，夢で はないかも知れない。

1) T. Muramatsu, S. Yokoyama, N. Horie, A. Matsuda, T. Ueda, Z. Yamaizumi, Y. Kuchino, S. Nishimura \& T. Miyazawa : J. Biol. Chem., 263, 9261 (1988).

2) T. Muramatsu, K. Nishikawa, F. Nemoto, Y. Kuchino, S. Nishimura, T. Miyazawa \& S. Yokoyama: Nature, 336, 179 (1988).

3) Y.-M. Hou \& P. Schimmel : Nature, 333, 140 (1988).

4) W. H. McClain \& K. Foss: Science, 240, 793 (1988).

5) L. H. Schulman \& J. Abelson: Science, 240, 1591 (1988).

6) M. Yarus : Cell, 55, 739 (1988).

（横山茂之, 東京大学理学部生物化学教室)

\section{糸状菌の生産する殺虫性物質オカラミン}

\section{天然培地を用いたカビによる有用物質の生産}

我々の生活を脅かす害虫を防除するために使用される 殺虫剤として, 現在 100 余りのものが登録されている. これらの多くは，有機リン酸エステル系化合物あるいは カーバメート系化合物, 塩素系化合物の有機合成化合物
でありより安全でより効果的な物質を求めて, 現在も さらに開発が進められている. その際に天然物がモデル 化合物として用いられる場合が多々ある.たとえば, 除 虫菊の殺虫成分ピレスリン類からのアレスリン, フェン 
バレレートなどに至る合成ピレスロ イドの開発あるいは，イソメの毒成 分ネレイソトキシンからの殺虫剤カ ルタップの開発などである，微生物 起源のものとしては, 高い殺ダ二活 性を有するミルペマイシン敃よび高 い殺線虫活性を有するアベルメクチ ンが神経系に作用点を持つことが明 らかにされ，近年特に注目されてき ている(1).

筆者らは，実用的な殺虫剤あるい は殺虫剤開発のリード化合物を得る ことを目的として，土壌微生物を対 象にランダムスクリーニングを行な った. ランダムスクリーニングの際 には多くの試料について検定できる ことが肝要であるので，被検昆虫と してカイコを用いることにした。ま た, 分離菌株の培養条件, 特に培地 として何を用いるかが，得られる生 産物にとって重要と思われる.

さて，日常生活においてミカンの 果皮の傷ついた所に青カビが生えて いるのや正月のモチに色とりどりのカビが生えているの をよく見かける．また，米や大豆などを原料として多く の醱酵食品が作られている.これらの事実は取りも直さ ず，天然物がそのまま微生物にとって良好な培地となる ことを物語っている. ところが，今までのところ天然培 地を用いて有用物質をスクリーニングした例はあまりな いようである，そこで，筆者らは天然培地の一つである オカラを用いて系状菌を対象に検索することにした. そ の結果, カイコに対して強い殺虫活性を有する一菌株 $\mathrm{AK}-40$ 株の分離に成功した.

菌学的性質の検討の結果, Penicillium simplicissimum と同定された AK-40 株をオカラで培養後, 菌体と培地 のアセトン抽出液を常法により酢酸エチルと水で分配し たところ, 前者に殺虫活性が認められた. この画分から 2 つの活性成分を結晶として単離し, 培地に因みオカラ ミンAおよびオカラミン $\mathrm{B}$ と命名した.

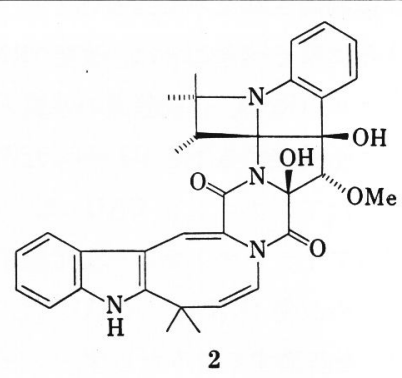<smiles>C=CC(C)(C)c1[nH]c2ccccc2c1CC1NC(=O)[C@@H]2[C@@H]3[C@@H](C[C@@H](O)c4ccccc4N2C(C)(C)C=C)N3C1=O</smiles>

5

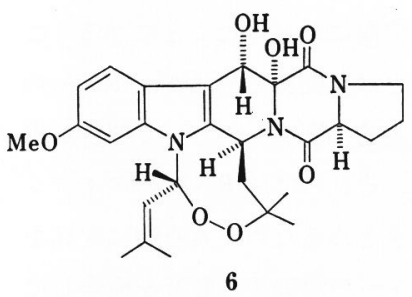

オカラミン $\mathrm{A}(1)$ とオカラミン $\mathrm{B}(2)$ はそれぞれ $\mathrm{C}_{32} \mathrm{H}_{32} \mathrm{~N}_{4} \mathrm{O}_{3}, \mathrm{C}_{33} \mathrm{H}_{34} \mathrm{~N}_{4} \mathrm{O}_{5}$ なる分子式を有し, いずれも 紫外部吸収スペクトルにおいて $375 \mathrm{~nm}$ 付近に極大吸収 を示し，類縁体であることが明らかとなった. オカラミ ンAの各種スペクトルデータおよびアセチル化体（3） の X線結晶解析により, オカラミン $\mathrm{A}$ の構造を図のよう に決定した (2). また，オカラミンBの構造は主に NMR スペクトルの比較検討により決定した(3). すなわち, オ カラミンAはピロロインドール部分とアゾシノインドー ル部分がジケトピペラジン環を介して結合した 7 環性化 合物であり， B はさらにピロール環にアゼチジン環が縮 合した 8 環性化合物であり，いずれも新規化合物であっ た。

筆者らはオカラミンの構造に興味をもち，このような 化合物が他の菌株によっても生産されるかどうかを知る ために, まずオカラミン生産菌 $\mathrm{AK}-40$ 株と同じ $P$. 
simplicissimum に属する他の菌株（IFO 5762，AHU 8065, AHU 8402, MF-24) についてオカラ培養時にお ける殺虫活性を調べた。その結果, AHU 8402 株に顕著 な活性が認められたので，AHU 8402 株の生産する殺虫 性物質を精製し，オカラミン $\mathrm{A}, \mathrm{B}$ の他にこれらの類縁 体（5）を明らかにした，5 はオカラミンAのアゾシン 環が閉環，脱水素される以前の化合物であり，生合成経 路に拉ける前駆物質と考えられる。

以上のようにして得られたオカラミン類はカイコに対 してどの程度の殺虫活性を示すのであううか，試料を餌 に混ぜ経口投与したところ，オカラミン A（1)および B（2）の L D 50 はそれぞれ $8 \mathrm{ppm}, 0.2 \mathrm{ppm}$ であっ た.アセチル化体（3）では $30 \mathrm{ppm}$ と活性が低くな りイソプレン側鎖の脱離した 4 ではまったく活性が認 められなかった，一方，アゾシン環の開裂した 5 は 1 と 同程度の活性を示した.すなわち，ピロロインドール部 分に結合したイソプレン側鎖が活性発現に重要な役割を 果たしていることが示唆された.

殺虫活性を有する物質も，害虫に対して活性を示して はじめて殺虫剤としての価值が見いだされる．そこで， オカラミンが害虫に対しても殺虫性を示すかどらかを， ニカメイガやュナガの 3 齢幼虫, イエバェの成虫なぞに ついて調ベた. その結果，オカラミンBがネギやサトイ モなどの害虫であるシロイチモンジョトウの 2 齢幼虫に $1 \mathrm{ppm}$ の低濃度で殺虫活性を示すことが明らかとなっ
た.

ところで，P.simplicissimum に属する菌株の代謝産物 について精査した時に興味ある現象を見いだした。すな わら, 研究室分離菌 MF-24 株の生産物を摂取したカイ コが痤攣様の症状を呈したのである.そこで, 痤㧛様作 用を指標として活性物質を精製単離し，ベルクロージェ ン（6）と同定した. 本物質は P. verruculosum から単 離され，マウスなどの動物に対して痤紧を与えることが 知られている(4). カイコを用いた簡便な生物検定で向神 経性物質を見いだし得ることが明らかとなり，神経系に 作用点を持つ物質の一次スクリーニングに本検定法が今 後役立つものと思われる.

以上述べてきた実験例は, 豆腐製造時の残椬であるオ カラを培地として用いることにより，糸状菌に興味ある 化合物を生産させることが可能となったものである.末 だ用いられずにある天然物を培地として利用することに よりまだまだ新規な代謝産物が微生物から得られるも のと期待される.

1) 田中啓司：農化誌, 61, 1601 (1987).

2) S. Murao, H. Hayashi, K. Takiuchi \& M. Arai : Agric. Biol. Chem., 52, 885 (1988).

3) H. Hayashi, K. Takiuchi, S. Murao \& M. Arai : Agric. Biol. Chem., 52, 2131 (1988).

4) J. F. Fayos, D. Lokensgard, J. Clardy, R. J. Cole \& J. W. Kirksey : J. Am. Chem. Soc., 96, 6785 (1974).

（林 英雄, 荒井基夫, 村尾澤夫*, 大阪府立大学農学 部，*熊本工業大学応用微生物工学科）

\section{魚類成長ホルモンの増養殖への利用}

\section{組換え体の微生物での生産に成功. 投与法など関連技術の開発が急務}

わが国の漁業は, 200 海里問題以後, 諸外国の沿岸か らの締め出しや漁獲量の規制などにより, 緊迫した状況 におかれつつある。一方, 消費の面からみれば，魚価の 上昇や調理の煩わしさにより“魚離れ”なる言葉が生み 出されているにもかかわらず，今な和日本人の動物タン パク質摂取量の半分は魚介類に依存しているというのが 現状である. それ故に, 食糧としての魚資源の確保は重 大な問題である.

さて, 近年バイオテクノロジーの発展と海洋資源の見 直しとが相まって, 官学産協同で, 海洋資源の利用・開
発について種々の会議やプロジェクトが計画され，ある いは実行され，その成果が実りつつある。これらの中に は，魚資源確保のための増養殖についての項目も含まれ ている，最近，その増養殖への応用のひとつとして，成 長ホルモン $(\mathrm{GH})$ の投与が考觉られている.

筆者らもこれまで，マグロ成長ホルモン $(\mathrm{tGH})$ につ いて種々の検討を加觉てきた.ここでは，筆者らの仕事 を中心に魚類の GH 研究について概説したい.

GH を魚類の増養殖に利用しょうという考えは，1930 年代からあった. その後, タンパク質の分離技術の進歩 
に伴い, サィ、ティラピア, コイ、チョウザメなどの脳 下垂体から GH が単離された。 わが国でも，川内らは シロザケ, 、マチ, カッオから, また岸田らはウナギか ら GH を単離した ${ }^{(1)}$. このらち, シロザケ, ウナギは協 和発酵との共同研究により GH cDNA が単離され, 大 腸菌(1) や酵母 ${ }^{(2)}$ での発現に成功している. 一方, 綿引 ら (1)は, 種々の動物 GH cDNA の共通塩基配列より推 定して作製したプローブを用いて, ブリの $\mathrm{GH} \mathrm{cDNA}$ を釣り上げた.これを松永ら ${ }^{(3)}$ は, 海洋性細菌 Rodopseudomonas sp. で発現させることに成功した. 最近で は,タイ(4), ヒラメ(5)などの GH cDNA の単離も報告 されている. GH の単離法については, 川内らの文献(1) や成書に, また cDNA の単離法については, 筆者らの 文献(6)や他の成書を参照されたい。

さて, 筆者らは, $t G H c D N A$ の発現の宿主としては 大腸菌を, 発現べターには IPTG (isopropyl- $\beta$-Dthiogalacto-pyranoside) で発現調節可能な pKK 223-3 を用いた. このベクターに, tGH cDNA のシグナル領 域を除いて 5'-末端に開始コドン（ATG）を付加した断 片（結果的に, Met-Ala-成熟 tGH をコードするように なった）を，SD-ATG 間の距離がそれぞれ 10，12， 13 および $15 \mathrm{bp}$ となるように挿入した組換えプラスミ ドを調製した。 これらを大腸菌 JM 109 に形質転換し, それぞれ 5 時間誘導培養した菌体を, 直接 SDS-PAGE に供し, 組換え $\mathrm{tGH}(\mathrm{rtGH})$ の生産量を測定した. し かしながら，いずれの組換它体においても生産量は1\% 以下であった。

そこで, Miki らの方法(7)に従い, 組換えプラスミド の複製開始点（ori）を pUC 19 のものと置換してみた. $\mathrm{pUC}$ 系のベクターも pBR 系と同様に col E 1 系の ori であるが, 制御系に变異が生じており, 大腸菌で細胞あ たり $\mathrm{pBR}$ 系の 10〜20 倍のコピー数が得られる。この 方法により pUC19 の ori と置換した組換えプラスミ ドを用いて，種々の大腸菌 (C 600, DH 1， HB 101, W 3110, JM 103, JM 105, JM 109）に形質転換し, そ れぞれの発現量をSDS-PAGE で測定した結果, SDATG 間が 13 bp で宿主をJM 109 としたとき, 全菌体 タンパク質あたり $13 \%$ の発現が認められた.これ以外 の組合せでは, いずれの場合も発現量は少なく, わずか
$1 \mathrm{bp}$ の違いでも，また宿主が異なっても発現量は大き く減少した.ささらに, SD-ATG 間が 13 bp の組換えプ ラスミドをタンデムに連結したものでは, 生産量が全菌 体タンパク質あたり 20〜30\% に達した.

ところで, 大腸菌で異種遺伝子を発現させた場合, 目 的タンパク質は不活性型の封入体を形成することが多 い.これを活性化するには, 尿素, 塩素グフニジン, SDS などの強力なタンパク質变性剤での処理やグルタ チオンなどの還元剤による処理が行なわれるが，目的の タンパク質の性質の違いによって，種々の条件を検討す る必要がある. 筆者らの $\mathrm{rtGH}$ は, 精製した封入体を $8 \mathrm{M}$ 塩酸グアニジン溶液中で処理することにより活性化 できた。これを逆相 HPLC で精製し，活性型 $\mathrm{rtGH}$ 得た.

さて, $\mathrm{GH}$ タンパク質の高次構造の改变による $\mathrm{GH}$ 活性への影響も検討されている，GH には 4 つの Cys 残基が存在し， $\mathrm{N}$-末端側から 1 番目と 2 番目， 3 番目之 4 番目の Cys がそれぞれ S-S 結合していることが知ら れている. ヒト GH の場合, この S-S 結合は活性に必

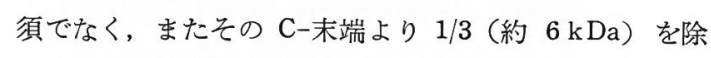
去しても活性が存在する。関根らは, シロザケ $\mathrm{GH}$ cDNA の C-末端側から， 58 残基のアミノ酸をコード する領域 (2, 3, 4 番目の Cys を含む) を除いても，そ の成長促進活性に影響しないことを明らかにした ${ }^{(8)}$ 。ま た, Chen らのグループは, ニジマス GH cDNA を用い て, site-directed mutagenesis 法により, これらのCys 残基を他のアミノ酸に置換することで，少なくとも 3 番 目と 4 番目の S-S 結合は GH 活性に寄与しないことを 明らかにした (T.Chen, 私信). 今後も, このような タンパク質工学的な手法を用いることによって，GH の 分子構造と活性との相関が明らかにされていくと考皃ら れる.

次に, 活性型 $\mathrm{rtGH}$ の生物活性を, ニジマス稚魚を用 いて調べた.すなわち, $\mathrm{rtGH}$ を 7 日怙きに 4 回, 腹腔 内に注射し, その体長と体重の増加率を生理食塩水を投 与したコントロール群と比較した. 投与量は, 体重 $\mathrm{g}$ あ たり $0.1 \mu \mathrm{g}$ と $0.5 \mu \mathrm{g}$ の 2 つ濃度で, それぞれ 10 尾を 1 群として検定した. この結果, $\mathrm{rtGH}$ 投与群は, コントロール群に比べて 28 日後には, 体長で約 $10 \%$, 
体重で約 $25 \%$ の増加が認められ，rtGH に顕著な成長 促進効果が認められることが判明した。 また, 慨料転換 効率も $\mathrm{rtGH}$ 投与群では約 $60 \%$ であったのに対してコ ントロールは約 40\% で, rtGH を投与することにより 䬣が効率的に利用されることも示唆された.なお゙, これ らの結果は, 脳下垂体から単離した $\mathrm{tGH}$ の効果と一致 した.これらの結果より, rtGH は増養殖に応用するこ とが可能であることが示されたので, 現在, 他の魚にも 同等の効果を与えるかどらか検討している.

ところで, GH の増養殖への利用で問題となるのは, その投与法である. 投与法として注射, 浸漬, あるいは 経口投与などが考学られるが，実用面からみれば経口投 与が一番簡便な方法であろう.川内らは, シロザケ $\mathrm{GH}$ をニジマスに経口投与した結果, 成長が促進されたと報 告している(1). 今後, この投与法の有効性について種々 の魚で検討する必要がある. また, 安全性についての基 礎的知見を集めることも急務である.さらに，アッセイ 系の簡便化が望まれる. 現在は飼育した魚の体長や体重 の増加で判定しているが, この方法は場所が限られ, 時 間がかかりすぎる欠点がある. 最近, 杉, 本らは, マウス
3T3-F442A 細胞を脂肪細胞に分化させる活性を指標と することで，活性測定を行なら技術を開発した(9). 成長 促進効果の指標としては, 間接的であるが, 短時間で簡 便にアッセイできる可能性があり, 今後の進展が待たれ る.

1) 川内浩司：化学と工業, 41(7), 106 (1988).

2）細井則子, 久我哲郎, 松本 正, 伊藤菁莪：日本分子生物学 会要旨集, 1987 , p. 125 .

3) 松永 是, 椿 和丈, 中島邦夫: 昭和 62 年度日本発酵工学 会要旨集, 1987, p. 65.

4) H. Momota, R. Kosugi, H. Hiramatsu, H. Ohgai, A. Hara \& H. Ishioka.: Nucleic Acids Res., 16(7), 3107 (1988).

5) M. Watahiki, M. Tanaka, N. Masuda, M. Yamakawa, Y. Yoneda \& K. Nakajima.: Gen. Comp. Endocrinol., 70, 401 (1988).

6) N. Sato, K. Watanabe, K. Murata, M. Sakaguchi, Y. Kariya, S. Kimura, M. Nonaka \& A. Kimura : Biochim. Biophys. Acta, 949, 35 (1988).

7) T. Miki, T. Yasukochi, H. Nagatani, M. Furuno, T. Orita, H. Yamada, T. Imoto \& T. Horiuchi : Protein Engineering, 1, 327 (1987).

8) 関根 進, 安部敏男, 伊藤菩莪: 日本分子生物学会要旨集, 1987, p. 125.

9）杉本整治, 森川 實, 横尾義春: 生化学, 60, 993 (1988).

(佐藤信行 ${ }^{* 1}$, 木村 光 $^{* 2}$, ${ }^{* 1}$ 大洋漁業大洋研究所, *2京都大学食糧科学研究所)

\section{強いゆばを作る}

\section{電解還元により大豆, 豆乳の加工適性を改善}

“心地よい温もりが，しだいに熱さに変わり，液面か らの水分の蒸発と液面に近い部位での成分変化のきざし が知覚されると，彼は急いでタンパク質に指示を与克 た.・.....タンパク質は, SS 結合をはじめとする疎水結 合や水素結合なと゚の手段を総動員して, 液面を保護する ための皮膜作りに奔走した. あわてふためいてはいて も，皮膜に柔軟性と各種のバリアー性を付与するための 微細な脂肪球のとり込みを忘れることはなかった。

間もなく彼は, 液面が皮膜によって招抒われ, 外界から しゃ断されたことを知って安心した。 しかし, 彼の安 心は長くは続かなかった。なぜなら，この皮膜こそ人間 から“ゆば”之呼ばれているものであり, 皮膜が完成す ると，すかさず取り上げられる運命にあるからである. そらなると，豆乳は，またしても自己保存本能の命ずる ままに，新たな皮膜の形成にとりかかるのである．こう
して, もはや指示に従らタンパク質と脂質が底をついた とき, 豆乳は自らの役目が終りに近づいたことを悟るの である.

豆乳にとっては，まことに迷惑至極な話ではあるが， このゆばこそ, 伝統的大豆食品のひとつとして古くから 親しまれてきたものであり，これからのわれわれの食生 活の向上や維持においても, 重要な役割をにならことが 期待されているものである.

ゆばの本質や有用性については，すでに詳しく紹介さ れており(1), 高い栄養価値と優れた保存性, 復元性, 調 理性などを兼㸚備えた食品であることは, 周知のと打り である、ところで，これほどの素材がどうしてこれま で，もっと広く利用されていなかったのか，その直接の 原因は，製造の合理化の遅れによるものである.ゆばの 製造は, その大部分を手作業に頼っているために, 大量 
生産が難しく, 手間がかかることなどから, 製造規模を 大きくできず，製造コストも他の大豆食品に比べて，か なり割高なものとなっている.ゆばを日常食品として普 及し, さらに食品素材として 低価格で供給するために は, 製造の機械化ならびに連続化が不可欠である.

ゆばの機械製造はこれまで, 主として皮膜のぜい弱さ が障害となって実用化がはばまれてきた。 ごく最近，あ る精密機械メーカーがゆばの機械製造に挑戦し, 実用規 模での製造を始めた(2). 製品の質もよく，注目に值する 成果であるが, 装置が皮膜のぜい弱さを補うために, 非 常に精密で高価なものとなってしまった．ゆばの機械製 造をもっと一般的な形で普及させるには, 製造装置をよ り簡易なものにしなければならない, そのためには，皮 膜の強度と形成速度をもら少し大きくする工夫が必要で ある. 皮膜強度は, 製造条件の変更によってある程度増 大させ得るが, 現行の製造条件は, 長年にわたる試行錯 誤の末に得られたもので, 強いゆばを製造するらえで, ほぼ最適条件となっている，国産大豆の中には，ゆばへ の加工適性が高く, 特に引張り強度が大きい皮膜を形成 できる品種もある. それでも, 比較的簡易な装置で連続 的に製造できるだけの強度は持ち合わせていない。

ゆば皮膜の形成には, タンパク質分子間の疎水結合や 水素結合, さらに SS 結合が関与していることが報告さ れて扣り, 特に SS 結合は皮膜の物理性, とりわけ, 強 度を大きく左右するとされている(3)，強いゆばを作るた めには, タンパク質分子間にできるだけ多くの SS 結合 を形成させることが必要である. ところで, タンパク質 分子間の SS 結合の形成は, 豆腐ゲルの製造においても 重要な役割を果たすことが知られている(4). 筆者は, 電 気分解に伴う陰極付近の還元状態を利用して, タンパク 質分子内または分子間に形成された SS 結合を還元し, $\mathrm{SH}$ 基を増加させることを主眼とする, 大豆の豆腐加工 適性改善技術を開発して，実用化した，具体的には，大 豆の浸漬中に電解還元処理を施すもので, 主として, 貯 蔵中に SS 結合を形成して不溶化したタンパク質の溶解 性が回復し, 豆乳の収率が向上するとともに, 増加した $\mathrm{SH}$ 基による SS 結合の形成が豆乳凝固時に追加される ことから, 豆腐の堅さが増大するなどの効果が得られ $た^{(5)}$.
電解還元による，このような大豆の加工適性の改善効 果は，当然ゆばの製造においても利用できるもので， 長期間貯蔵した大豆や，ゆばへの加工適性が低い大豆か らでも，強いゆばを製造でさることが予测されるささら に, SH 基による SS 結合の形成は, 酸化によって促進 されることから, 電気分解に伴ら陽極付近の酸化状態を 利用して，皮膜の形成速度を加速することができる．す なわち，豆乳容器を金属製として陰極に，また豆乳の液 面に金属製の回転ドラムを接触させて陽極にすれば，陰 極である豆乳容器の壁面付近では, 電解還元によって $\mathrm{SS}$ 結合が開裂して, 皮膜強度の増大につながる $\mathrm{SH}$ 基 の増加が起こる. 一方, 回転ドラムの付近では, 電解酸 化によって SS 結合の形成が促進されて, 皮膜の形成が 加速される．両極間に適切な電圧を印加することによっ て, 強い皮膜を比較的短時間に形成させ，巻さ上げるこ とができるわけである.

このような方法の実用化においては，まだいくつかの 改善すべき点が残されているが，豆乳を少量ずつ補充す ることによって，試験的には，成分組成の変動が小さい ゆばを連続的に製造できることが認められた，また，回 転ドラムが豆乳に接する面積と印加する電圧をさらに増 大させると，回転ドラムに接した豆乳中では水素イオン 濃度が増大して pH が低下し，豆乳中のタンパク質が酸 凝固して回転ドラムの表面に付着してくる.ドラムの回 転に伴って, この上にゆばが張り合わさり, 薄い豆腐と ゆばを積層した構造を持つ素材がでさる.この素材は， ゆばの加工利用において, またひとつ, 新しい可能性を 加えるものである.

強いゆばの製造が起点となって, 製造の合理化が推進 され，日常食品としての普及に加劣て，加工食品や組立 食品用素材としてのゆばの利用が広がってゆくことを期 待してやまない。

1) 岡本 奨: “食の科学”, 丸ノ内出版, 1976, p. 128.

2) 株式会社 ミットヨ (宇都宮市).

3) 白井正澄, 渡辺 研, 岡本 奖: 日食工誌, 21, 324 (1974).

4) K. Saio, M. Kajikawa \& T. Watanabe: Agric. Biol. Chem., 35, 890 (1971).

5) 米安 実: 醹協, $81,771,840$ (1986).

（米安 実, 広島県立食品工業技術センター） 